\title{
Canine endogenous adrenocorticotrophic hormone preanalytical stability after sample shipping in dry ice or recyclable ice bars
}

\section{Álan Gomes Pöppl ${ }^{1^{*}}$ (i) Carolina Castilhos da Silva ${ }^{1}$ Guilherme Luiz Carvalho de Carvalho ${ }^{1}$ (I) Rogério Soila ${ }^{2}$ (D) Priscila Viau Furtado ${ }^{3}$ (D)}

${ }^{1}$ Serviço de Endocrinologia e Metabologia Veterinária, Hospital de Clínicas Veterinárias da Universidade Federal do Rio Grande do Sul, 91540-000, Porto Alegre, RS, Brasil. E-mail: gomespoppl@hotmail.com. .Corresponding author.

${ }^{2}$ PROVET Medicina Veterinária Diagnóstica, Laboratório de Hormônios, São Paulo, SP, Brasil.

${ }^{3}$ Laboratório de Hormônios, Faculdade de Medicina Veterinária e Zootecnia, Universidade de São Paulo (USP), Butantã, SP, Brasil.

ABSTRACT: Endogenous adrenocorticotrophic hormone (eACTH) measurement is useful in hypercortisolism and hypoadrenocorticism investigation; however, since the hormone is highly unstable, blood samples require proper processing and storage, as well as shipping is often a step limiting since few laboratories offer this assay in Brazil. The aim of this note was to compare overnight dog's eACTH preanalytical stability when frozen samples were shipped in dry ice (DI), or with recyclable ice bars (RIB). A total of 56 paired samples for eACTH measurement were analyzed. Blood samples were properly handled, plasma aliquots transferred into plastic microtubes, and stored at $-80^{\circ} \mathrm{C}$. The fifty-six paired samples were overnight shipped in two thermic isolated boxes with DI or involved by RIB. Despite there was a high correlation between results from both shipping methods $(r$ Spearman $=0.958, P<0.001)$, the Wilcoxon matched-pairs rank test showed that the shipping method may influence results $(P<0.001)$. However, this difference does not affect results interpretation. By this way, when DI shipping was not possible, RIB shipping may represent a risk to eACTH preanalytical stability.

Key words: ACTH determination, shipping method, hyperadrenocorticism, hypercortisolism, hypoadrenocorticism.

Estabilidade pré-analítica do hormônio adrenocorticotrófico endógeno canino após remessa de amostras em gelo seco ou com barras de gelo reciclável

RESUMO: A mensuração do hormônio adrenocorticotrófico endógeno (ACTHe) é útil na investigação do hipercortisolismo e hipoadrenocorticismo. No entanto, como o hormônio é bastante instável, as amostras de sangue necessitam um manejo adequado no processamento e armazenamento, assim como o envio para laboratórios pode ser um passo limitante, uma vez que poucos laboratórios oferecem este ensaio no Brasil. O objetivo deste trabalho foi comparar a estabilidade pré-analitica do ACTHe durante longo periodo de envio de amostras congeladas em gelo seco (GS), ou com barras de gelo reciclável (BGR). Um total de 56 amostras pareadas para mensuração de ACTHe foram analisadas. As amostras de sangue foram adequadamente manejadas, sendo o plasma transferido para micro tubos plásticos estocados a $-80^{\circ} \mathrm{C}$. Os 56 pares de amostras foram enviados à tarde para chegada ao laboratório na manhã seguinte em dois isopores, um com GS e outro com BGR. Apesar de uma alta correlação entre os resultados dos diferentes métodos de envio ( $r$ Spearman $=0,958$, $P<0,001)$, o teste de Wilcoxon para amostras pareadas mostrou que o método de envio influencia os resultados $P<0,001)$. Apesar desta diferença, os resultados não afetaram a interpretação dos resultados. Desta forma, quando o envio em gelo seco não for possível, o envio das amostras com barras de gelo reciclável pode representar um risco à estabilidade pré-analítica do ACTHe.

Palavras-chave: mensuração de ACTH, método de remessa, hiperadrenocorticismo, hipercortisolismo, hipoadrenocorticismo.

Endogenous adrenocorticotrophic hormone (eACTH) measurement is a useful tool in the diagnostic approach and classification of some endocrine diseases. In both naturally occurrence hypercortisolism (Cushing's syndrome) and hypoadrenocorticism (Addison's syndrome), eACTH measurements may help differentiation between primary or secondary origin (GOULD et al., 2001; SHIEL \& MOONEY, 2019). Primary hypercortisolism, in which function adrenocortical tumor (adrenal-dependent hypercortisolism - HAD) autonomously produces cortisol, as well as secondary hypoadrenocorticism, in which hypophyseal hypofunction lead to adrenocortical insufficiency, are conditions associated with supressed serum eACTH concentration (GOULD et al., 2001; SHIEL \& 
MOONEY,2019). In contrast, high, or very high; serum eACTH concentration are expected in conditions such secondary hypercortisolism (pituitary-dependent hypercortisolism - PDH) (BEHREND et al., 2013), primary hypoadrenocorticism (LATHAN et al., 2014), and due to trilostane medical treatment of Cushing's syndrome (TESHIMA et al., 2009). Distinguish PDH from $A D H$ is imperative while defining therapeutic goals (SANDERS et al., 2018). The same is true when primary and secondary hypoadrenocorticism are considered. While the former depends on glucocorticoid and mineralocorticoid lifelong supplementation, the latter depends only on glucocorticoid replacement (SHIEL \& MOONEY, 2019).

Preanalytical factors such as sampling, processing, and storage influence eACTH concentration in whole blood samples since plasma proteases rapidly degrade the hormone (CHRISTENSEN et al., 2016; WU \& XU, 2016). Therefore, to an accurate measurement, blood samples should be collected into refrigerated siliconcoated glass or plastic EDTA tubes, centrifuged preferentially in a refrigerated centrifuge $\left(4{ }^{\circ} \mathrm{C}\right)$ within $15 \mathrm{~min}$ of collection, the plasma transferred to plastic tubes and immediately frozen, then shipped frozen (typically overnight, packed in dry ice) to the laboratory or stored at $-80{ }^{\circ} \mathrm{C}$ (TALBOT et al, 2003; WU \& XU, 2016; BEHREND et al, 2013; BENNAIM et al., 2019). However, few commercial laboratories offer canine eACTH measurement in Brazil. By this way, shipping samples to reference labs may become a dangerous preanalytical step if the material is not properly sent. Therefore, the present note compares overnight dog's eACTH preanalytical stability when frozen samples were shipped in dry ice, or with recyclable ice bars, from a referral endocrinology service to a reference laboratory.

A total of 17 dogs with confirmed PDH by means of compatible clinical signs and laboratory abnormalities, adrenal ultrasound morphology, and positive results in the low-dose dexamethasonesuppression test (LDDST) were enrolled in this study. Patients were evaluated at initial diagnosis before trilostane treatment start, and longitudinally along the treatment after one, three, and six months at the Veterinary Clinics Hospital's Endocrinology and Metabolism Service of the Federal University from Rio Grande do Sul (HCV-UFRGS). The study was approved by the Ethics Committee on the Use of Animals (CEUA-UFRGS) and informed consent concordance was obtained from all participant owners. A total of 56 samples for eACTH measurement were analyzed over time. Blood samples $(4 \mathrm{~mL})$ were collected by vacuum from jugular vein in EDTA pre-cold tubes. After collection, samples were immediately centrifuged (room temperature, 3000 rpm for 3 minutes). Plasma aliquots $(500 \mu \mathrm{L})$ were then transferred into plastic microtubes and stored at $-80{ }^{\circ} \mathrm{C}$ until being sent to a reference laboratory (PROVET, Medicina Diagnóstica, São Paulo). The fifty-six paired samples were sent in two thermic isolated boxes $(23 \times 18 \times 14 \mathrm{~cm})$, one with $2 \mathrm{~kg}$ of dry ice (DI - "gold-standard") and the other with samples involved by three $18 \times 10 \times 3 \mathrm{~cm}$ each recyclable ice bars (RIB). Thermic boxes were additionally revested with newspaper paper, sealed and overnight shipped. The time since samples were retired from the $-80{ }^{\circ} \mathrm{C}$ freezer in Porto Alegre until they reach the lab in São Paulo was around 18 hours.

Instead DI samples were received adequately frozen at the lab, RIB samples arrived unfrozen, but still cold. Therefore, RIB aliquots were immediately analyzed, while DI samples were analyzed after unfrozen. Plasma eACTH concentrations were determined with Immulite ACTH, a two-site solid-phase chemiluminescent immunometric assay (ACTH Kit, Immulite 1000 analyzer, Siemens ${ }^{\circledR}$ ), previously validated for dogs (SCOTT-MONCRIEFF et al., 2003), accordingly with manufacturer instructions. Manufacturer-supplied information indicated an analytical sensitivity for the assay of $5 \mathrm{pg} / \mathrm{mL}$ and a working range of 5-1250 pg/mL. For assay accuracy, two internal controls were used with different ACTH concentrations: $10 \mathrm{pg} / \mathrm{mL}$ (reading: $9.47 \mathrm{pg} / \mathrm{mL}$ ), and $60 \mathrm{pg} / \mathrm{mL}$ (reading: $58.16 \mathrm{pg} / \mathrm{mL}$ ).

The overall difference between aliquots shipped in DI or RIB are showed in figure 1. Despite there was a high correlation between results from both shipping methods (r Spearman $=0.958$, $\mathrm{P}<0.001$ ), and a relative small difference in mean and median values within groups (Table 1); the Wilcoxon matched-pairs rank test showed that the shipping method may influence final results $(\mathrm{P}<0.001)$. The overall effect of sample shipping with RIB was a mean reduction of $19.2 \%$ in comparison with their pairs sent in DI. This reduction ranged from $-180 \%$ to $-0.92 \%$. Nevertheless, thirteen from 56 samples (23.2\%) showed higher eACTH values (mean 15.8\%, median 5.3\%, and range: 0.3 to $50.4 \%$ ) when shipped in RIB compared with DI. Despite this huge variation in some pairs, individual case classification would not change in this case series regarding patients with Cushing's syndrome. However, four samples (7.14\%) shipped in RIB had results falling below reference range, while their pairs sent in DI were at lower range of the reference interval. Table 2 shows 


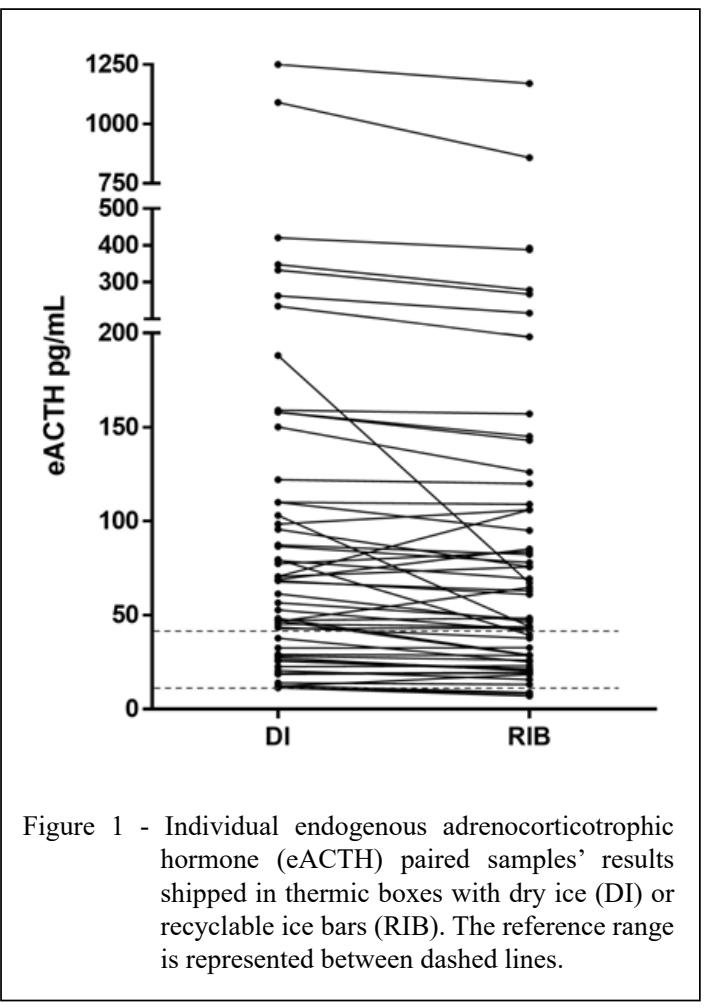

individual sample pairs' results of eACTH shipped in dry ice (DI) or with recyclable ice bars (RIB), and their respective percentual variation.

The reference interval for canine eACTH using the above-mentioned chemiluminescent assay is $10-45 \mathrm{pg} / \mathrm{mL}$. Generally, is expected that patients with PDH shows high eACTH, while dogs with ADH have low values (BEHREND et al., 2013; BENNAIN et al., 2019). However, the assumption that a dog has $\mathrm{ADH}$ in terms of eACTH measurement is made when undetectable (i.e $<5 \mathrm{pg} / \mathrm{mL}$, below the lower limit of detection of this assay) results are documented associated with adrenal morphology at abdominal ultrasound. This precaution is of special interest since dogs with PDH may show eACTH ranging from 6 to $1250 \mathrm{pg} / \mathrm{mL}$ which is the upper limit of detection of the assay (GOULD et al, 2001; TALBOT et al, 2003). Despite acceptable, eACTH within reference range or below in patients with PDH may represent problems related to time between sampling and centrifugation, as well as sample storage or shipping. Other rare possibility that could be evaluated in these cases is the coexistence of $\mathrm{PDH}$ and $\mathrm{ADH}$, when adrenal and pituitary imaging will represent even more valuable tolls (BENNAIN et al., 2019).

Endogenous ACTH measurement may also play a role during treatment monitoring of dogs with hypercortisolism treated with trilostane, since the higher eACTH values, the greater the risk for iatrogenic hypoadrenocorticism (KING \& MORTON 2017). Steroid synthesis inhibition decreases patient's cortisolemia, leading to a loss of any negative feedback in the axis, and enlarged eACTH secretion (TESHIMA et al, 2009). In fact, the outliers higher eACTH results obtained in our study were documented in dogs' samples on trilostane treatment. It was shown in rat models, and is accepted that the same occurs in dogs, that chronic higher eACTH overtime are associated with higher histologic alterations index in adrenal cortex, characterized mainly by hemorrhage, vacuolization, and apoptosis (BURKHARDT et al., 2011). A possible effect of trilostane or trilostane metabolites are also considered (KING \& MORTON 2017). In this scenario, a suppressed eACTH concentration secondary from preanalytical issues would induce one to neglect hypoadrenocorticism risk.

Despite it was not the case, if the samples of this study were collected from dogs with hypoadrenocorticism, in which the primary and most common form of the disease is associated with pretty high eACTH concentrations (LATHAN et al., 2014), results interpretation would not change also, since secondary hypoadrenocorticism is associated with undetectable eACTH results (SHIEL \& MOONEY 2019). Knowing the fragility of eACTH and the

Table 1 - Range of results, median, mean, and standard error from 56 frozen paired samples overnight shipped for endogenous adrenocorticotropic hormone measurement in dry ice or in recyclable ice bars.

\begin{tabular}{lcccc}
\hline Shipping Method & Results Range & Median & Mean \pm SE & Reference Interval \\
\hline Dry Ice & $11.4-1250$ & 68 & $126.7 \pm 16.1$ & $10-45 \mathrm{pg} / \mathrm{mL}$ \\
Recyclable Ice Bar & $6.99-1171$ & 54.8 & $106.3 \pm 14.2$ & \\
\hline
\end{tabular}

SE. standard error. 
Table 2 - Individual sample pairs' results of eACTH shipped in dry ice (DI) or with recyclable ice bars (RIB), and their respective percentual variation.

\begin{tabular}{|c|c|c|c|c|c|c|c|}
\hline $\begin{array}{l}\text { Sample } \\
\text { pair }\end{array}$ & $\begin{array}{c}\text { eACTH } \\
(\mathrm{pg} / \mathrm{mL}) \mathrm{DI}\end{array}$ & $\begin{array}{c}\text { eACTH } \\
(\mathrm{pg} / \mathrm{mL}) \mathrm{RIB}\end{array}$ & Variation (\%) & Sample pair & $\begin{array}{c}\text { eACTH } \\
(\mathrm{pg} / \mathrm{mL}) \mathrm{DI}\end{array}$ & $\begin{array}{c}\text { eACTH } \\
\text { (pg/mL) RIB }\end{array}$ & Variation $(\%)$ \\
\hline 1 & 1250 & 1171 & -6.3 & 29 & 67.7 & 63 & -6.9 \\
\hline 2 & 1091 & 859 & -21.2 & 30 & 61.3 & 46.5 & -24.1 \\
\hline 3 & 506 & 393 & -22.3 & 31 & 56.6 & 47.8 & -15.5 \\
\hline 4 & 421 & 388 & -7.8 & 32 & 52.8 & 41.9 & -20.6 \\
\hline 5 & 348 & 279 & -19.8 & 33 & 48.3 & 28.9 & -40.1 \\
\hline 6 & 333 & 268 & -19.5 & 34 & 47.3 & 48.5 & +2.5 \\
\hline 7 & 263 & 216 & -17.8 & 35 & 47 & 28.6 & -39.1 \\
\hline 8 & 235 & 198 & -15.7 & 36 & 46.6 & 64.8 & +39.1 \\
\hline 9 & 188 & 67,1 & -64.3 & 37 & 45.4 & 43.7 & -3.7 \\
\hline 10 & 159 & 157 & -1.2 & 38 & 43.6 & 37.8 & -13.3 \\
\hline 11 & 158 & 144 & -8.8 & 39 & 42.8 & 43.3 & +1.2 \\
\hline 12 & 158 & 143 & -9.4 & 40 & 37.8 & 25.2 & -33.3 \\
\hline 13 & 150 & 126 & -16 & 41 & 32.6 & 32.7 & +0.3 \\
\hline 14 & 122 & 120 & -1.6 & 42 & 29.1 & 28.5 & -2.1 \\
\hline 15 & 110 & 109 & -0.9 & 43 & 28.2 & 26 & -7.8 \\
\hline 16 & 110 & 95 & -13.6 & 44 & 27.4 & 20.3 & -25.9 \\
\hline 17 & 103 & 44 & -57.2 & 45 & 26.1 & 21.5 & -17.6 \\
\hline 18 & 98.4 & 106 & +7.7 & 46 & 25.6 & 20.9 & -18.3 \\
\hline 19 & 95.6 & 75.8 & -20.7 & 47 & 22.6 & 23.1 & +2.2 \\
\hline 20 & 87.3 & 82.3 & -5.7 & 48 & 20.6 & 15.8 & -23.3 \\
\hline 21 & 86.5 & 78 & -9.8 & 49 & 19.1 & 19.5 & +2.1 \\
\hline 22 & 79.6 & 39.4 & -50.5 & 50 & 18.6 & 19.2 & +3.2 \\
\hline 23 & 79 & 69.3 & -12.2 & 51 & 14 & 13.1 & -6.4 \\
\hline 24 & 77.4 & 83.7 & +8.1 & 52 & 12.6 & 8.9 & -29.4 \\
\hline 25 & 70.6 & 106 & +50.1 & 53 & 12.3 & 18.5 & +50.4 \\
\hline 26 & 70.5 & 75.7 & +7.3 & 54 & 12 & 8.3 & -30.7 \\
\hline 27 & 68.9 & 85.2 & +23.6 & 55 & 11.7 & 7.2 & -38.5 \\
\hline 28 & 68.3 & 61.1 & -10.5 & 56 & 11.4 & 6.9 & -38.6 \\
\hline
\end{tabular}

risk of many preanalytical steps suppress plasma hormone concentration, even low detectable results obtained in dogs with hypoadrenocorticism should put away secondary hypoadrenocorticism hypothesis, since there is no recent glucocorticoids administration history (CHASTAIN \& GRAHAM 1979; BROCKUS et al., 1999).

Thus, despite the apparent feasibility of RIB packing for eACTH samples' overnight shipping, DI packing still is and should continue to be the standard shipping method. The fact that some samples showed higher results in the RIB pairs in comparison with the DI pair is difficult to understand and explain since all samples and hormone measurements followed the strict same conditions of processing, handling, and storage. However, despite all care with samples, we believe an unidentified preanalytical factor may have affected dry ice pairs potentially causing this up-variation in few RIB pairs. These results are helpful to increase eACTH measurement in the routine evaluation of dogs with hypercortisolism and hypoadrenocorticism. However, other basic principles step-limiting to ensure eACTH stability are needed. Blood collection in pre-cooled plastic tubes with EDTA, keep samples in ice flakes while waiting for centrifugation, freeze plasma immediately after centrifugation, and shipping frozen plasma to a reference laboratory (if needed), are mandatory to avoid eACTH degradation.

\section{ACKNOWLEDGEMENTS}

The authors would like to thank to the PROVET Medicina Diagnóstica for their support to conduct this study. 
This study received grants from CAPES (Coordenação de Aperfeiçoamento de Pessoal de Nível Superior - Código de financiamento 001).

\section{BIOETHICS AND BIOSSECURITY COMMITTEE APPROVAL}

We authors of the article entitled "Evaluation of dog's endogenous adrenocorticotrophic hormone preanalytical stability processed in non-refrigerated centrifuge" declare, for all due purposes, that the project that gave rise to the present data has been approved by the Veterinary Faculty Research Committee (COMPESQ) and by the Universidade Federal do Rio Grande do Sul's (UFRGS) Ethics Committee on the Use of Animals (CEUA), project number 31681 .

\section{DECLARATION OF CONFLICTS OF INTERESTS}

The authors declare no conflict of interest. The founding sponsors had no role in the design of the study; in the collection, analyses, or interpretation of data; in the writing of the manuscript, and in the decision to publish the results.

\section{AUTHORS' CONTRIBUTIONS}

AGP, RS, and PVF conceived and project study's design. AGP, CCS, and GLCC conducted the case series and were responsible for sample collection, processing, and shipping. RS and PVF were responsible for hormone measurements. AGP and CCS prepared the manuscript. All authors revised and agreed with manuscript definitive version.

\section{REFERENCES}

BEHREND, E. N. et al. Diagnosis of spontaneous canine hyperadrenocorticism: 2012 ACVIM Consensus Statement (Small Animal). Journal of Veterinary Internal Medicine, v.27, p.12921304, 2013. Available from: <http://onlinelibrary.wiley.com/doi/10.1111/ jvim.12192/references $>$. Accessed: Jan. 5, 2017. doi: 10.1111/jvim. 12192.

BENNAIM, M. et al. Diagnosis of spontaneous hyperadrenocorticism in dogs. Part 2: Adrenal function testing and differentiating tests. The Veterinary Journal, v.252, 105343, 2019. Available from: <https://www.sciencedirect.com/science/ article/pii/S1090023319300784>. Accessed: Mar. 29, 2020. doi: 10.1016/j.tvj1.2019.105343.

BROCKUS, C. W. et al. Effect of alternate-day prednisolone administration on hypophyseal-adrenocortical activity in dogs. American Journal of Veterinary Research, vol.60, p.698702, 1999. Available from: <https://www.ncbi.nlm.nih.gov/ pubmed/10376895>. Accessed: Mar. 29, 2020.

BURKHARDT, W. A. et al. Adrenocorticotropic hormone, but no trilostane, causes severe adrenal hemorrhage, vacuolization, and apoptosis in rats. Domestic Animal Endocrinology, v.40, p.155-164, 2011. Available from: <https://www.ncbi.nlm.nih.gov/pubmed/21194873>. Accessed: Mar. 29, 2020. doi: 10.1016/j.domaniend.2010.10.002.

CHASTAIN, C. B.; GRAHAM, C. L. Adrenocortical suppression in dogs on daily and alternate-day prednisone administration. American Journal of Veterinary Research, vol.40, p.936-
941, 1979. Available from: <https://www.ncbi.nlm.nih.gov/ pubmed/507496>. Accessed: Mar. 29, 2020.

CHRISTENSEN, $M$. et al. Whole blood samples for adrenocorticotrophic hormone measurement can be stored at room temperature for 4 hours. Scandinavian Journal of Clinical and Laboratory Investigation, v.76, p.653-656, 2016. Available from: $<$ http://www.tandfonline.com/doi/full/10.1080/00365513.2016.1230 887>. Accessed: Jan. 5, 2017. doi: 10.1080/00365513.2016.1230887.

GOULD, S. M. et al. Use of endogenous ACTH concentration and adrenal ultrasonography to distinguish the cause of canine hyperadrenocorticism. Journal of Small Animal Practice, v.42, p.113-121, 2001. Available from: <http://onlinelibrary.wiley.com/ doi/10.1111/j.1748-5827.2001.tb02007.x/abstract>. Accessed: Feb. 10, 2017. doi: 10.1111/j.1748-5827.2001.tb02007.x.

KING, J. B.; MORTON, J. M. Incidence and risk factor for hypoadrenocorticism in dogs treated with trilostane. The Veterinary Journal, v.230, p.24-29, 2017. Available from: $<$ https://www.ncbi.nlm.nih.gov/pubmed/29208212>. Accessed: Mar. 29, 2020. doi: 10.1016/j.tvj1.2017.10.018.

LATHAN, P. et al. Use of Cortisol-to-ACTH ration for diagnosis of primary hypoadrenocorticism in dogs. Journal of Veterinary Internal Medicine, v.28, p.1546-1550, 2014. Available from: $<$ https://onlinelibrary.wiley.com/doi/full/10.1111/jvim.12392>. Accessed: Mar. 29, 2020. doi: 10.1111/jvim.12392.

SANDERS, K. et al. Treating canine Cushing's syndrome: Current options and future prospects. The Veterinary Journal, v.241, p.42-51, 2018. Available from: <https://www.ncbi.nlm.nih.gov/pubmed/30340659>. Accessed: Mar. 29, 2020. doi: 10.1016/j.tvjl.2018.09.014.

SCOTT-MONCRIEFF, J. C., et al. Validation of a chemiluminescent enzyme immunometric assay for plasma adrenocorticotropic hormone in the dog. Veterinary Clinical Pathology, v.32, p.180-187, 2003. Available from: <https://pubmed.ncbi.nlm.nih.gov/14655102/>. Accessed: Jul. 27, 2020. doi: 10.1111/j.1939-165x.2003.tb00333.x.

SHIEL, R. E.; MOONEY, C. T. Redefining the paradigm of atypical hypoadrenocorticism in dogs. Companion Animal, v.24, p.14-22, 2019. Available from: <https://www.magonlinelibrary. com/doi/abs/10.12968/coan.2019.24.3.132>. Accessed: Mar. 29, 2020. doi: $10.12968 /$ coan.2019.24.3.132.

TALBOT, J. A. et al. Analytical and clinical aspects of adrenocorticotropin determination. Annals of Clinical Biochemistry: International Journal of Laboratory Medicine, v.40, p.453-471, 2003. Available from: <http://journals.sagepub. com/doi/pdf/10.1258/000456303322326371>. Accessed: Jan. 5, 2017. doi: $10.1258 / 000456303322326371.0$

TESHIMA, T. et al. Trilostane-induced inhibition of cortisol secretion results in reduced negative feedback at the pituitaryhypothalamic axis. Domestic Animal Endocrinology, v.36, p.3244, 2009. Available from: <http://www.sciencedirect.com/science/ article/pii/S0739724008001112>. Accessed: Apr. 26, 2017. doi: 10.1016/j.domaniend.2008.10.002.

WU, Z. Q.; XU, H. G. Preanalytical stability of adrenocorticotropic hormone depends on both time to centrifugation and temperature. Journal of Clinical Laboratory Analysis, online version of record published before inclu0sion in an issue, p.1-3, 2016. Available from: <http://onlinelibrary.wiley.com/woll/doi/10.1002/jcla.22081/ abstract $>$. Accessed: Jan. 5, 2017. doi: 10.1002/jcla.22081.

Ciência Rural, v.51, n.1, 2021. 